\title{
THE PRESENCE OF GAD AND IA-2 AUTO ANTI-BODIES IN YOUNG ADULTS DIAGNOSED AS TYPE 2 DIABETES MELLITUS
}

\begin{abstract}
Venkatramani Mahadevan', Alagianambi Shanmugam², Duraisamy Venkatesh ${ }^{3}$, Thayanithi Jayapackiam ${ }^{4}$, Stephen Charles Bronson ${ }^{5}$, Duvuru Shantharam ${ }^{6}$
\end{abstract}

\author{
1 Junior Resident, Institute of Cardiology, Madras Medical College, Chennai. \\ ${ }^{2}$ Associate Professor, Institute of Diabetology, Stanley Medical College, Chennai. \\ ${ }^{3}$ Senior Resident, Department of Diabetology, Coimbatore Medical College, Coimbatore. \\ ${ }^{4}$ Assistant Professor, Institute of Diabetology, Stanley Medical College, Chennai. \\ ${ }_{5}$ Senior Resident, Institute of Diabetology, Stanley Medical College, Chennai. \\ ${ }^{6}$ Director \& Professor, Institute of Diabetology, Stanley Medical College, Chennai.
}

\begin{abstract}
\section{BACKGROUND}

Diabetes Mellitus is a metabolic cum vascular disease, cause of which is mainly due to defect in insulin secretion from the $\beta$ cell of islet of pancreas or defect in the action of insulin. ${ }^{1,2}$ Diabetes mellitus is marked by chronic high glucose concentration in plasma. The resultant hyperglycaemia which in long run lead to serious damage and dysfunction of many vital body organs especially the blood vessels and nerves. Symptoms of diabetes recognition dates back to 1550 B.C where diabetes was described as melting ${ }^{3}$ down of the flesh and limbs into urine and for the patients never stop making water. Diabetes in Greek means siphon - to explain the liquefaction of the flesh and bone into urine; Mellitus means honeyed urine.

Objectives- To study the presence of GAD and IA-2 antibodies in young adults diagnosed as Type 2 Diabetes phenotypically and to assess the ability of auto antibodies to discriminate between Type 1 diabetes and Type 2 diabetes whose treatment differs.
\end{abstract}

\section{MATERIALS AND METHODS}

This is a cross sectional study and it was conducted at Institute of Internal Medicine and Institute of Diabetology, Madras Medical College and Rajiv Gandhi Government General Hospital for a period of 6 months from July 2011.

\section{RESULTS}

Total number of participants in this study was 82 in number. In this study group 43(52.44\%) were females and 39 (47.56\%) were males. On analysis of 82 people for the presence of autoantibodies to GAD-65 and IA-2, 7 were positive which represents $8.53 \%$ in percentage. Of the two autoantibodies, antibodies to GAD was prevalent in adults and was seen in 6 peoples whereas IA-2 was seen in one patient and none of the patients in this study showed positivity for both autoantibodies.

\section{CONCLUSION}

Screening of autoantibodies is useful to distinguish between type 1 diabetes and type 2 diabetes in young.

\section{KEYWORDS}

Diabetes Mellitus, Glutamic Acid Decarboxylase, Insulinoma Associated Protein 2 Autoantibody.

HOW TO CITE THIS ARTICLE: Mahadevan V, Shanmugam A, Venkatesh D, et al. The presence of GAD and IA-2 auto anti-bodies in young adults diagnosed as type 2 diabetes mellitus. J. Evolution Med. Dent. Sci. 2017;6(3):185-192, DOI: 10.14260/Jemds/2017/45

\section{BACKGROUND}

Diabetes Mellitus is a major threat to the public health in this world. The entire globe is now facing a new hazardous challenge in the form of growing epidemic of diabetes mellitus. Diabetes mellitus is well known for its potentially devastating damage and dysfunction to the organs from head to toe and can occur in all age group from paediatric population to geriatric population.

Financial or Other, Competing Interest: None.

Submission 04-12-2016, Peer Review 26-12-2016,

Acceptance 03-01-2017, Published 09-01-2017.

Corresponding Author:

Dr. Alagianambi Shanmugam,

Associate Professor,

Institute of Diabetology,

Government Stanley Medical College,

Chennai-01.

E-mail: drshanmugaa@gmail.com

DOI: $10.14260 /$ jemds $/ 2017 / 45$

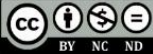

Diabetes is arising as an epidemic especially in young age people which is a worrisome fact. The rise in diabetes mellitus among the young people is bewildering as the rise may be due to earlier age of onset of type 2 diabetes ${ }^{3,4}$ or slow onset of type 1 diabetes. Recent studies show that due to restricted physical activity and consumption of high calorie diet in children, there is high incidence of childhood obesity. Obesity which sets the clock on for insulin resistance in childhood may contribute to the earlier development of type $2 \mathrm{DM}$ at young age. The rise in the earlier onset type 2 diabetes may be also due to urbanization and parental diabetes. Due to rapid increase in obesity among general population, even people diagnosed as type 1 diabetes are obese or overweight at the time of diagnosis. ${ }^{5}$

\section{MATERIALS AND METHODS}

This is a cross sectional study and it was conducted at Institute of Internal Medicine and Institute of Diabetology, Madras Medical College and Rajiv Gandhi Government General Hospital for a period of 6 months from July 2011. 
The protocol for this study was approved by Institutional Ethical Committee (IEC), Madras Medical College - Rajiv Gandhi Government General Hospital, Chennai - 600003.

\section{Inclusion Criteria for Participation in the Study-}

1. Type 2 diabetes mellitus - phenotypically diagnosed as per WHO guidelines.

2. Age less than 40 years.

3. No diabetes related complications at time of enrolment into the study.

4. No other co-existing autoimmune disease.

5. Diabetes patients on oral hypoglycaemic agents with or without Insulin.

\section{Exclusion Criteria}

1. Not willing to participate in the study after clear explanation.

2. History of diabetic ketoacidosis in the past.

3. Micro or macro vascular diabetic complications.

4. Pregnant diabetes patients.

5. Patients known to have pancreatitis disease.

6. Patients with autoimmune disease.

7. Patients on drugs that may be the cause of diabetes.

After meticulous assessment of inclusion and exclusion criteria, 82 patients were enrolled in this study. Verbal explanation about the study was clearly enlightened to the participants and their doubts in the study was addressed and clarified. From those are willing to enrol in the study an informed consent in the prescribed format submitted to ethical committee was obtained. Participants who can't understand English language, the consent form was obtained in their mother tongue (Tamil) so that the participants can have better understanding about the study details.

From the eligible subjects, history such as the duration of diabetes, onset of the disease, cause of detection and family history of diabetes with types were asked and noted in the prescribed format. Regarding treatment, details about diabetes management as well as other diseases were then recorded.

These subjects were subjected to general examination and anthropometric measurements were recorded. In anthropometry height, weight, calculation of BMI by the formula using height and weight, waist hip ratio were recorded. External markers for insulin resistance like acanthosis nigricans, hirsutism were made out by inspection. Tape marked in centimeters was used to measure the height and it was measured to nearest centimeter. To measure the height participants were requested to stand upright without any foot wear with heels together. They are requested to look forward while measuring the height. Universally accepted and calibrated weighing machine was utilized to assess the weight of the participants. Weight was calibrated to the nearest rounded kg without decimals. Weigh machine was kept on a level flat surface while measuring. Wearing of thin cloths which will not interfere with weight was allowed. To assess the obesity or overweight body mass index (BMI) was calculated. BMI was calculated by dividing weight in kilogram by height in meter square. Reference for body mass index in our study was adopted from the guidelines released by Health Ministry- Government of India, Indian Council of Medical Research (ICMR) and the National Institute of Nutrition (NIN).
Body Mass Index for Indian Population-

\begin{tabular}{|c|c|}
\hline Less than 18.4 & Underweight \\
\hline $18.5-22.9$ & Normal \\
\hline $23-24.9$ & Overweight \\
\hline More than 25 & Obese \\
\hline
\end{tabular}

Measurement of blood pressure was done in a quiet room, patient in seated position for 5 minutes. Well calibrated and accepted blood pressure machine with appropriate cuff size working on mercury scale was used to measure the resting blood pressure. Blood pressure was recorded in the two arms and the highest of these two recording were mentioned. Patients who are on medication for blood pressure control were allowed the take the morning dose as scheduled and BP was recorded under the productive cover of antihypertensive only.

\section{Waist Circumference}

Waist circumference is used to assess the central obesity. Measurement of waist circumference was done at the midpoint between the iliac crest and sub costal margin with the help of non-stretching tape. Waist circumference of the participants where measured in standing position with feet together and measurement was rounded to the nearest whole number. Thin layer of cloth is allowed on measuring the circumference. For Indian men cut-off limit for waist circumstances is below $90 \mathrm{~cm}$ as opposed to $102 \mathrm{~cm}$ worldwide and in case for Indian women it is $80 \mathrm{~cm}$ as opposed to $88 \mathrm{~cm}$ at the worldwide.

\section{Assays and Calculations}

Under sterile precaution, sufficient blood samples were drawn both in fasted and post prandial state. Biochemical investigations were done at quality control laboratory at Institute of Diabetology, Rajiv Gandhi Government General Hospital, Chennai. Fasting samples were utilized for assessing fasting plasma glucose, lipid profile, renal parameter, cpeptide, insulin auto antibodies like GAD 65 and IA-1. Postprandial blood sample was drawn 2 hours from the ingestion of breakfast with scheduled anti diabetic medication the patient is taking already.

Fasting plasma glucose and post prandial plasma glucose were tested by Glucose Oxidase - Peroxidase method using the validated semi-autoanalyser named Erba Mannheim cehm plus-7.

Urea was estimated by Urease-Glutamate dehydrogenase (GLDH) method and creatinine was assessed by modified Jaffe's method by means of the same semi-autoanalyser named Erba Mannheim cehm plus-7. With the use of semiautoanalyser named Erba Mannheim cehm plus-7. lipid profile was estimated. Total cholesterol was assessed by cholesterol oxidase-peroxidase (CHOD-PAP) method, triglycerides by Glycerophosphate oxidase-peroxidase (GPOPAP) method and high density lipoprotein was estimated by third generation direct homogeneous assay. Low density lipoprotein was calculated by using the Friedewald equation for the sample with triglycerides less than $400 \mathrm{mgs} / \mathrm{dl}$. Urine was test for the estimation of spot protein by $3 \%$ sulphosalicylic acid test and normal urine spot protein patients were included in the study. 
Immunological assays such as estimation of C-peptide level and autoantibodies such as GAD-65 as well as IA-2 were done at central lab, department of Immunology, the Tamil Nadu Dr. M. G. R. Medical University, Chennai using the ELISA technique in quality control Elisa reader made be Biorad. GAD-65 estimation was done by using the Euroimmun AntiGAD IgG Elisa kit and IA-2 was done by using Euroimmun Anit- IA2 IgG Elisa.

To determine the presence of metabolic syndrome in these individuals, NCEP ATP III (National Cholesterol Education Program Adult Treatment Panel III). Criteria were used.

\section{NCEP ATP III Criteria-}

1. Blood pressure $\geq 130 / 85 \mathrm{mmHg}$ or $\leq 130 / 85 \mathrm{mmHg}$ with antihypertensive medications.

2. Fasting plasma glucose $\geq 6.1 \mathrm{mmol} / \mathrm{l}(110 \mathrm{mgs} / \mathrm{dl})$.

3. HDL cholesterol $<40 \mathrm{mg} / \mathrm{dl}$ for men or $<50 \mathrm{mg} / \mathrm{dl}$ for women,

4. Triglycerides $>150 \mathrm{mgs} / \mathrm{dl}$ or patients on medication with fibrate drugs.

5. Waist circumference (WC) cut-offs were taken as $>90 \mathrm{~cm}$ for males and $>80 \mathrm{~cm}$ for females to define overweight.

As Indians have higher body fat content than their western counterparts for the same BMI, lower cut-offs of waist circumference were used as suggested by Asia-Pacific guidelines in contrast the globally accepted waist circumference $\geq 102 \mathrm{~cm}$ for men or $\geq 88 \mathrm{~cm}$ for women.

The diagnosis of the metabolic syndrome required individuals to have at least three of these five criteria. Because all subjects in this report had diabetes, they only had to have two of the remaining four criteria to meet the definition.

\section{Statistical Method}

Data reported in this study include descriptive statistics of the participants at the time of enrolment. Qualitative variables in this study such as sex, family history etc. are analysed by chi-square test. The quantitative data in this study were analysed using independent sample $t$ test

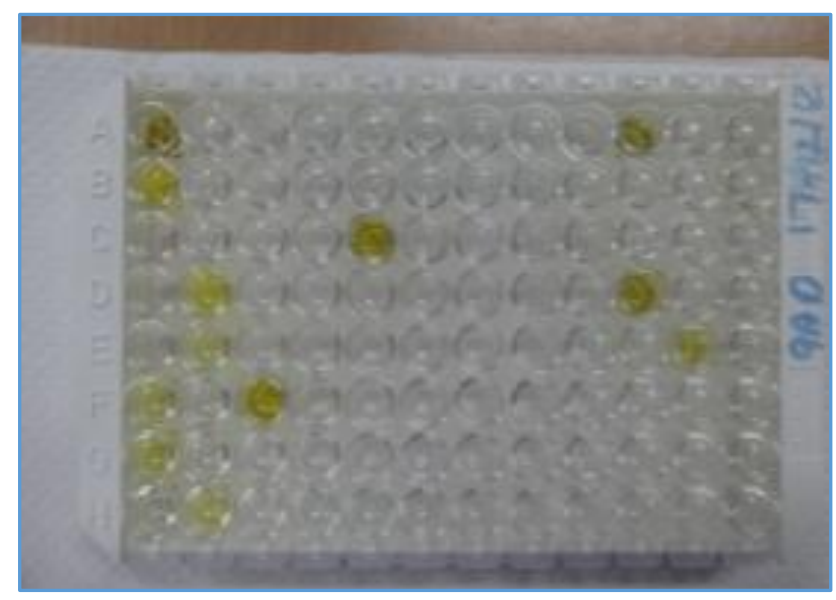

Anti-Gad Antibodies Positive Picture

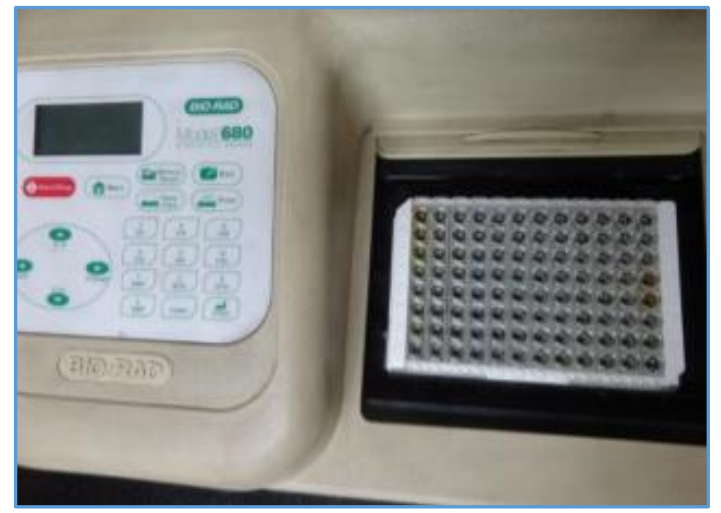

Anti-Ia2 Antibodies Positive

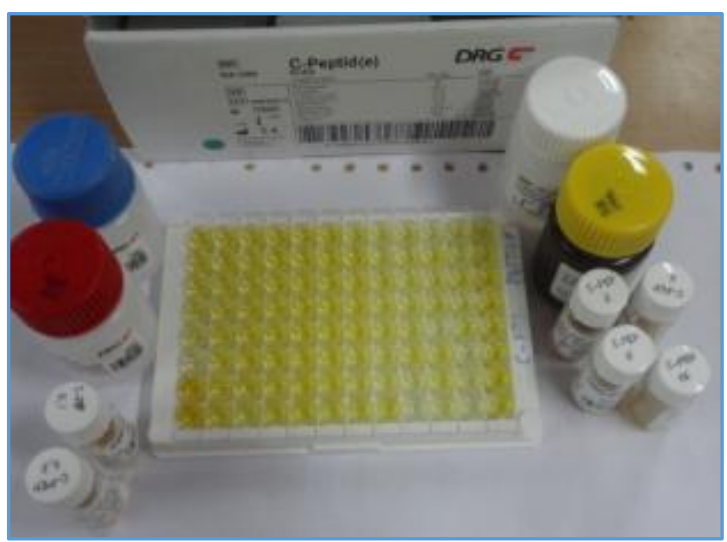

Fastingt C-Peptide Testing

\section{RESULTS}

Demographic Profile

\begin{tabular}{|c|c|c|}
\hline $\begin{array}{c}\text { Age Group } \\
\text { (In years) }\end{array}$ & $\begin{array}{c}\text { Auto Antibodies } \\
\text { Positive }\end{array}$ & $\begin{array}{c}\text { Auto Antibodies } \\
\text { Negative }\end{array}$ \\
\hline $15-20$ & 0 & 5 \\
\hline $21-30$ & 5 & 27 \\
\hline $31-40$ & 2 & 44 \\
\hline \multicolumn{2}{|c|}{ Age groups and Auto-antibodies positivity }
\end{tabular}

\section{Age and Auto- antibodies positivity}

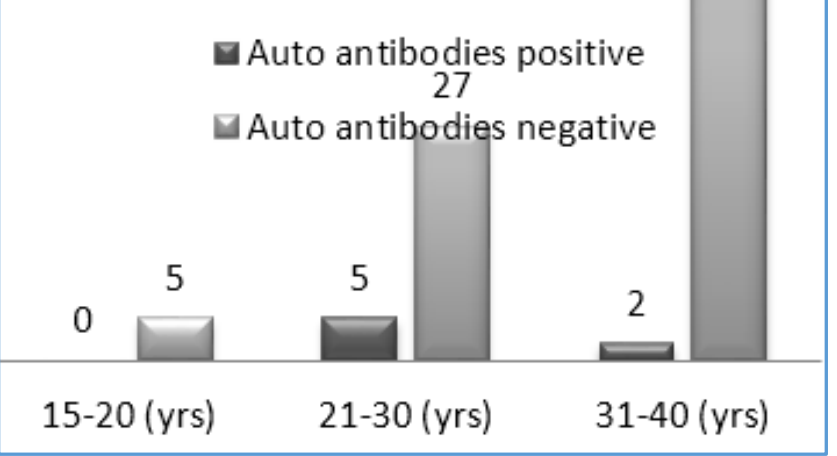




\begin{tabular}{|c|c|c|}
\hline Sex & $\begin{array}{c}\text { Auto-Antibodies } \\
\text { Positivity }\end{array}$ & $\begin{array}{c}\text { Auto-Antibodies } \\
\text { Negativity }\end{array}$ \\
\hline Males & 5 & 34 \\
\hline Females & 2 & 41 \\
\hline \multicolumn{2}{|c|}{ Sex and Auto antibody positivity } \\
\hline
\end{tabular}

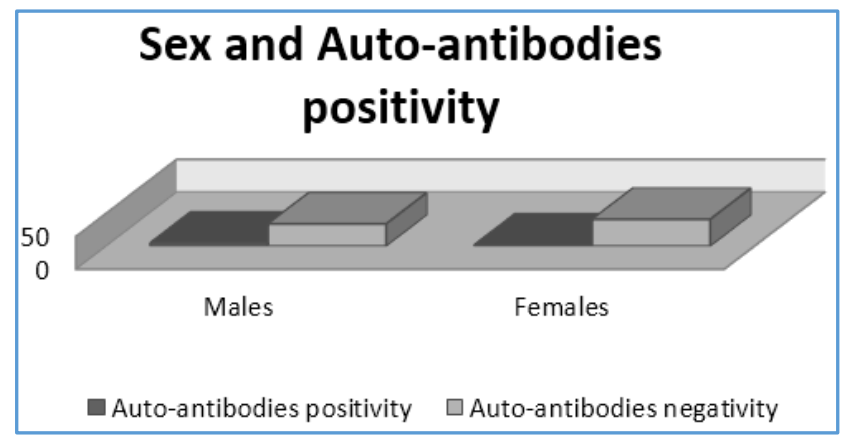

\begin{tabular}{|c|c|c|}
\hline $\begin{array}{c}\text { Duration of } \\
\text { Diabetes } \\
\text { (In Years) }\end{array}$ & $\begin{array}{c}\text { No. of Auto- } \\
\text { Antibodies } \\
\text { Positive Cases }\end{array}$ & $\begin{array}{c}\text { No. of Auto- } \\
\text { Antibodies } \\
\text { Negative Cases }\end{array}$ \\
\hline$\leq 2$ & 6 & 51 \\
\hline$>2$ & 1 & 24 \\
\hline \multicolumn{2}{|c|}{ Duration and Auto-antibodies positivity } \\
\hline
\end{tabular}

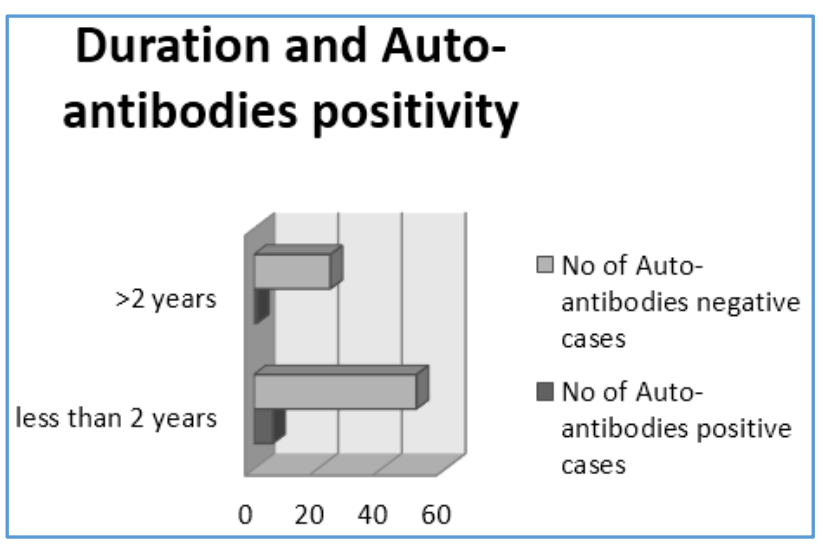

\begin{tabular}{|c|c|c|}
\hline $\begin{array}{c}\text { Family History } \\
\text { of Diabetes }\end{array}$ & $\begin{array}{c}\text { No. of Auto- } \\
\text { Antibodies } \\
\text { Positive Cases }\end{array}$ & $\begin{array}{c}\text { No. of Auto- } \\
\text { Antibodies } \\
\text { Negative Cases }\end{array}$ \\
\hline Present & 2 & 42 \\
\hline Absent & 5 & 33 \\
\hline \multicolumn{2}{|c|}{ Family history of Diabetes and Auto-antibodies } \\
\hline
\end{tabular}

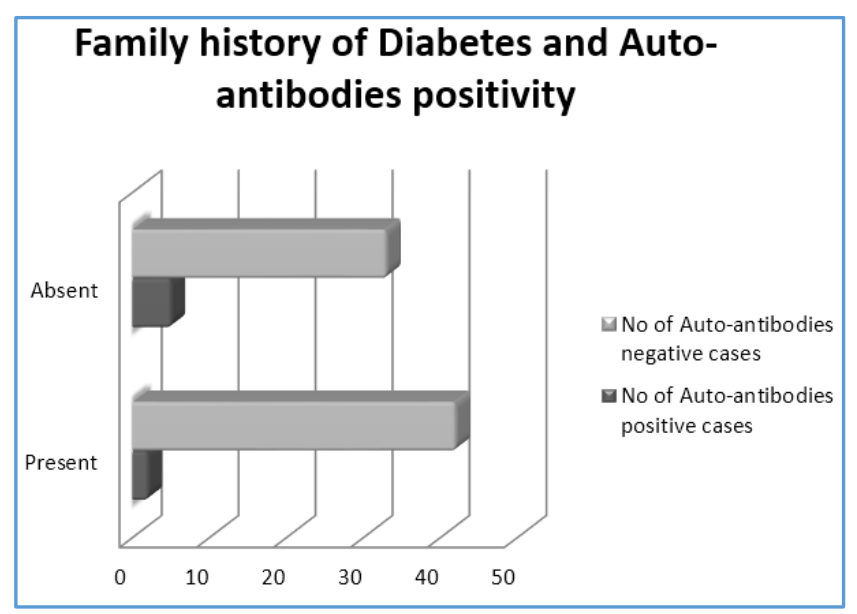

\begin{tabular}{|c|c|c|}
\hline BMI & $\begin{array}{c}\text { No. of Auto- } \\
\text { Antibodies } \\
\text { Positive Cases }\end{array}$ & $\begin{array}{c}\text { No. of Auto- } \\
\text { Antibodies } \\
\text { Negative Cases }\end{array}$ \\
\hline $18-22.9$ & 4 & 16 \\
\hline $23-24.9$ & 2 & 11 \\
\hline$>25$ & 1 & 14 \\
\hline \multicolumn{2}{|c|}{ BMI and Auto-antibodies positivity } \\
\hline
\end{tabular}

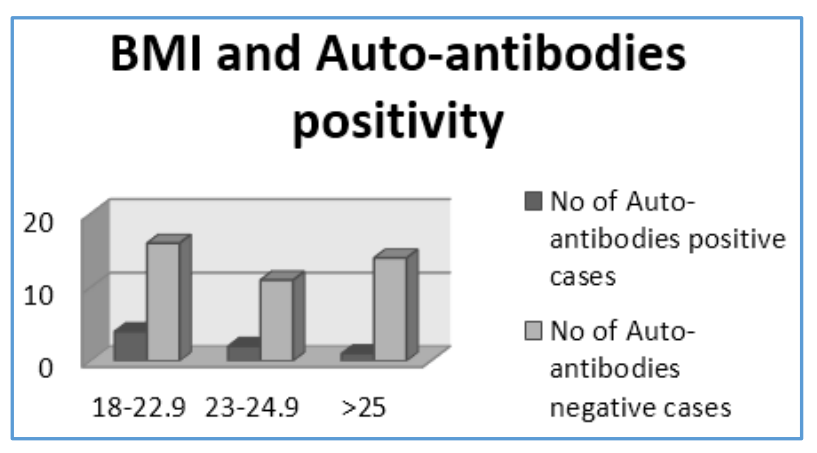

\begin{tabular}{|c|c|c|}
\hline $\begin{array}{c}\text { Circumference for } \\
\text { Men (In cm) }\end{array}$ & $\begin{array}{c}\text { No. of Auto- } \\
\text { Antibodies } \\
\text { Positive Cases }\end{array}$ & $\begin{array}{c}\text { No. of Auto- } \\
\text { Antibodies } \\
\text { Negative Cases }\end{array}$ \\
\hline$<90$ & 4 & 27 \\
\hline$>90$ & 1 & 7 \\
\hline \multicolumn{3}{|c|}{ Waist circumference for men } \\
\hline
\end{tabular}

\section{Waist circumference in men}

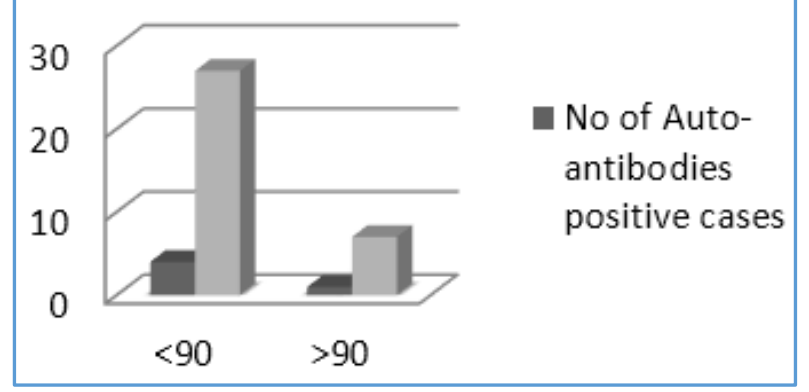

\begin{tabular}{|c|c|c|}
\hline $\begin{array}{c}\text { Waist Circumference } \\
\text { for Women (In cm) }\end{array}$ & $\begin{array}{c}\text { No. of Auto- } \\
\text { Antibodies } \\
\text { Positive Cases }\end{array}$ & $\begin{array}{c}\text { No. of Auto- } \\
\text { Antibodies } \\
\text { Negative Cases }\end{array}$ \\
\hline$<80$ & 2 & 11 \\
\hline$>80$ & 0 & 30 \\
\hline \multicolumn{2}{|c|}{ Waist circumference for women } \\
\hline
\end{tabular}

\section{Waist circumference in women and Auto- antibodies positivity}

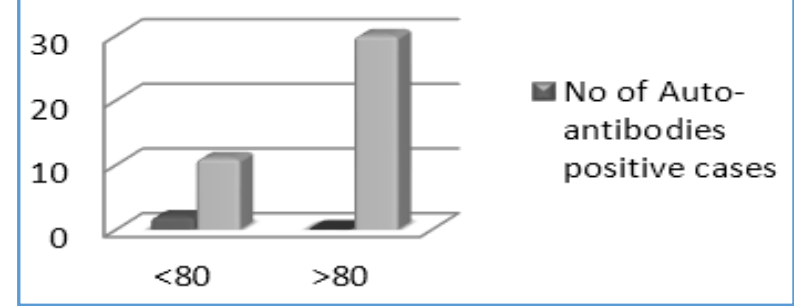




\begin{tabular}{|c|c|c|}
\hline $\begin{array}{c}\text { Systolic BP } \\
\text { (mmHg) }\end{array}$ & $\begin{array}{c}\text { No. of Auto-Anti- } \\
\text { bodies Positive } \\
\text { Cases }\end{array}$ & $\begin{array}{c}\text { No. of Auto-Anti- } \\
\text { bodies Negative } \\
\text { Cases }\end{array}$ \\
\hline$>130$ & 0 & 68 \\
\hline$<130$ & 7 & 7 \\
\hline \multicolumn{2}{|c|}{ Systolic BP and Auto-antibodies } \\
\hline
\end{tabular}

\section{Systolic BP and Auto- antibodies positivity}

No of Auto-antibodies positive cases

$\square$ No of Auto-antibodies negative cases

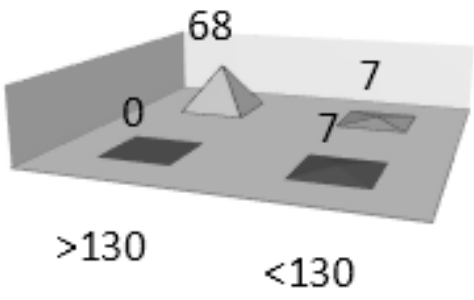

\begin{tabular}{|c|c|c|}
\hline $\begin{array}{c}\text { Diastolic } \\
\text { BP }\end{array}$ & $\begin{array}{c}\text { No. of Auto-Anti- } \\
\text { bodies Positive Cases }\end{array}$ & $\begin{array}{c}\text { No. of Auto-Anti- } \\
\text { bodies Negative Cases }\end{array}$ \\
\hline$>85$ & 3 & 68 \\
\hline$<85$ & 4 & 7 \\
\hline \multicolumn{2}{|c|}{ Diastolic BP and Auto-antibodies positivity } \\
\hline
\end{tabular}

\section{Diastolic BP and Auto- antibodies positvity}

No of Auto-antibodies positive cases

$\square$ No of Auto-antibodies negative cases

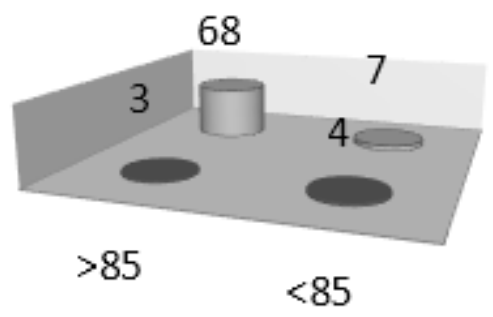

\begin{tabular}{|c|c|c|}
\hline $\begin{array}{c}\text { Insulin } \\
\text { Use }\end{array}$ & $\begin{array}{c}\text { No of Auto-Antibodies } \\
\text { Positive Cases }\end{array}$ & $\begin{array}{c}\text { No of Auto-Antibodies } \\
\text { Negative Cases }\end{array}$ \\
\hline Yes & 2 & 16 \\
\hline No & 5 & 59 \\
\hline \multicolumn{2}{|c|}{ Insulin use and Auto-antibodies } \\
\hline
\end{tabular}

\section{Insulin use and Auto- antibodies positivity}

No of Auto-antibodies positive cases

$\square$ No of Auto-antibodies negative cases

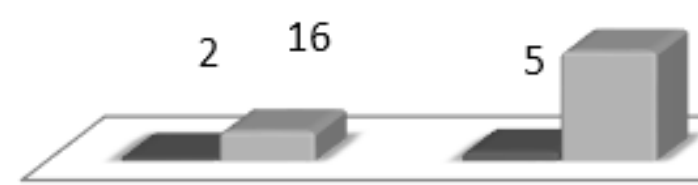

Yes

No

\begin{tabular}{|c|c|c|}
\hline $\begin{array}{c}\text { Acanthosis } \\
\text { Nigricans }\end{array}$ & $\begin{array}{c}\text { No. of Auto- } \\
\text { Antibodies } \\
\text { Positive Cases }\end{array}$ & $\begin{array}{c}\text { No. of Auto- } \\
\text { Antibodies } \\
\text { Negative Cases }\end{array}$ \\
\hline Yes & 0 & 19 \\
\hline No & 7 & 52 \\
\hline \multicolumn{2}{|c|}{ Acanthosis Nigricans and Auto-antibodies Positivity } \\
\hline
\end{tabular}

\section{Acanthosis Nigricans and Auto-antibodies positivity}

No of Auto-antibodies positive cases

$\square$ No of Auto-antibodies negative cases

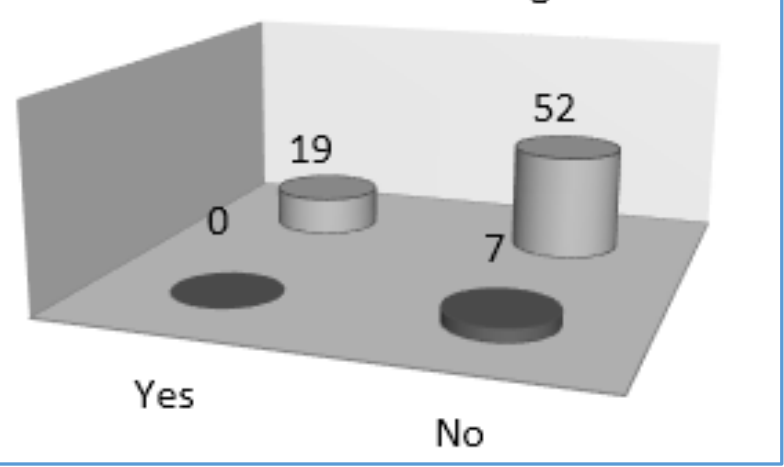

\begin{tabular}{|c|c|c|}
\hline $\begin{array}{c}\text { Triglycerides } \\
\text { (In mg/dl) }\end{array}$ & $\begin{array}{c}\text { No. of Auto- } \\
\text { Antibodies } \\
\text { Positive Cases }\end{array}$ & $\begin{array}{c}\text { No. of Auto- } \\
\text { Antibodies } \\
\text { Negative Cases }\end{array}$ \\
\hline$>150$ & 6 & 39 \\
\hline$<150$ & 1 & 36 \\
\hline \multicolumn{2}{|c|}{ Triglycerides and Auto-antibodies positivity } \\
\hline
\end{tabular}




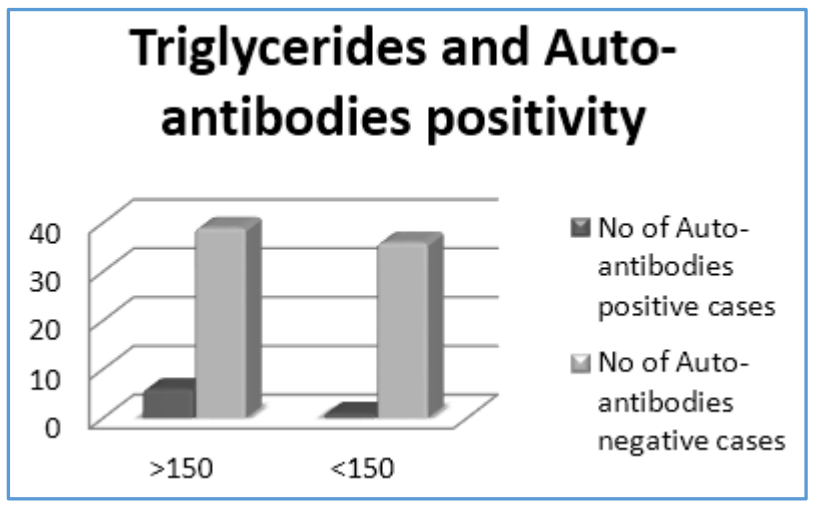

\begin{tabular}{|c|c|c|}
\hline $\begin{array}{c}\text { HDL in } \\
\text { Males }\end{array}$ & $\begin{array}{c}\text { No. of Auto-Antibodies } \\
\text { Positive Cases }\end{array}$ & $\begin{array}{c}\text { No. of Auto-Antibodies } \\
\text { Negative Cases }\end{array}$ \\
\hline$>40$ & 4 & 14 \\
\hline$<40$ & 1 & 20 \\
\hline \multicolumn{3}{|c|}{ HDL in males and Auto-antibodies } \\
\hline
\end{tabular}

\section{HDL in males and Auto-antibodies}

No of Auto-antibodies positive cases

$\square$ No of Auto-antibodies Negative cases

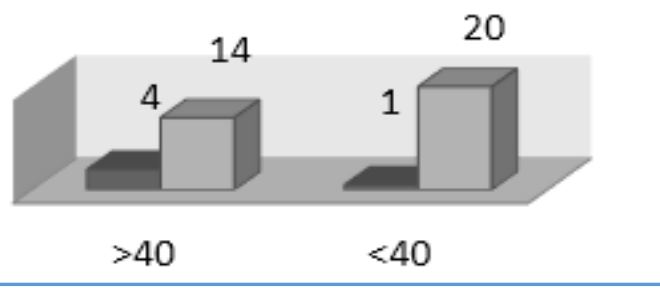

\begin{tabular}{|c|c|c|}
\hline $\begin{array}{c}\text { HDL in } \\
\text { Females }\end{array}$ & $\begin{array}{c}\text { No. of Auto-Antibodies } \\
\text { Positive Cases }\end{array}$ & $\begin{array}{c}\text { No. of Auto-Antibodies } \\
\text { Negative Cases }\end{array}$ \\
\hline$>50$ & 0 & 0 \\
\hline$<50$ & 2 & 41 \\
\hline \multicolumn{3}{|c|}{ HDL in females and Auto-antibodies } \\
\hline
\end{tabular}

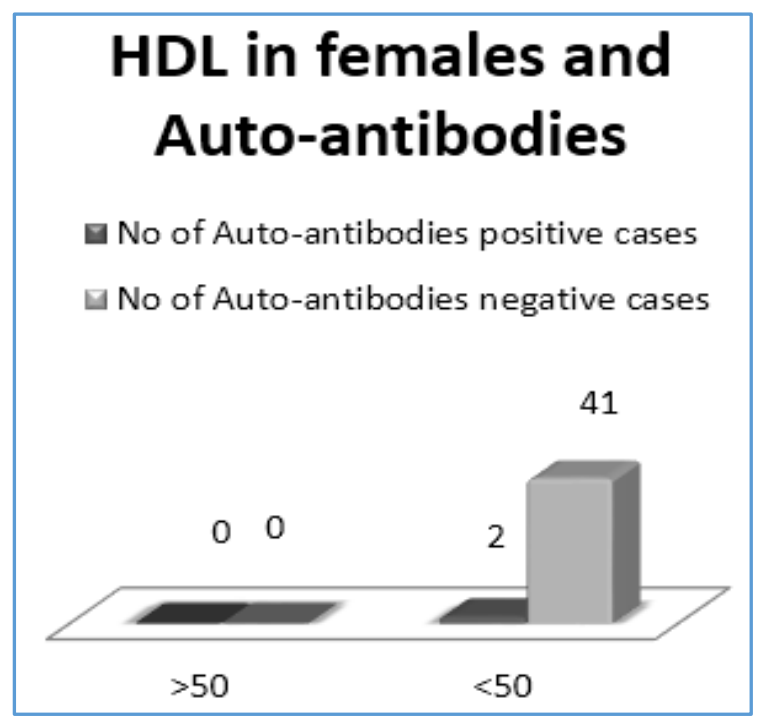

\begin{tabular}{|c|c|c|}
\hline $\begin{array}{c}\text { Fasting C-Peptide } \\
\text { Level }\end{array}$ & $\begin{array}{c}\text { No. of Auto- } \\
\text { Antibodies } \\
\text { Positive Cases }\end{array}$ & $\begin{array}{c}\text { No. of Auto- } \\
\text { Antibodies } \\
\text { Negative Cases }\end{array}$ \\
\hline Normal & 0 & 70 \\
\hline Low & 7 & 5 \\
\hline \multicolumn{2}{|c|}{ Fasting C-Peptide level and Auto-antibodies } \\
\hline
\end{tabular}

\section{Fasting C-Peptide and Auto-antibodies positivity}

$\square$ No of Auto-antibodies positive cases
$\square$ No of Auto-antibodies negative cases

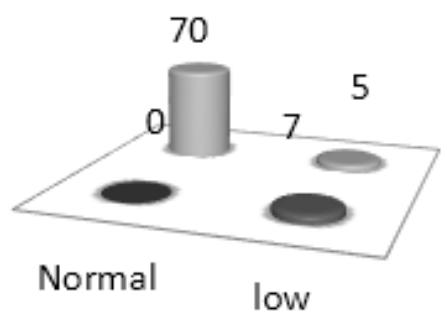

\begin{tabular}{|c|c|c|}
\hline FPG & $\begin{array}{c}\text { No. of Auto-Antibodies } \\
\text { Positive Cases }\end{array}$ & $\begin{array}{c}\text { No. of Auto-Antibodies } \\
\text { Negative Cases }\end{array}$ \\
\hline$<130$ & 0 & 1 \\
\hline$>130$ & 7 & 74 \\
\hline \multicolumn{2}{|l|}{ Fasting Plasma Glucose and Auto-antibodies positivity } \\
\hline
\end{tabular}

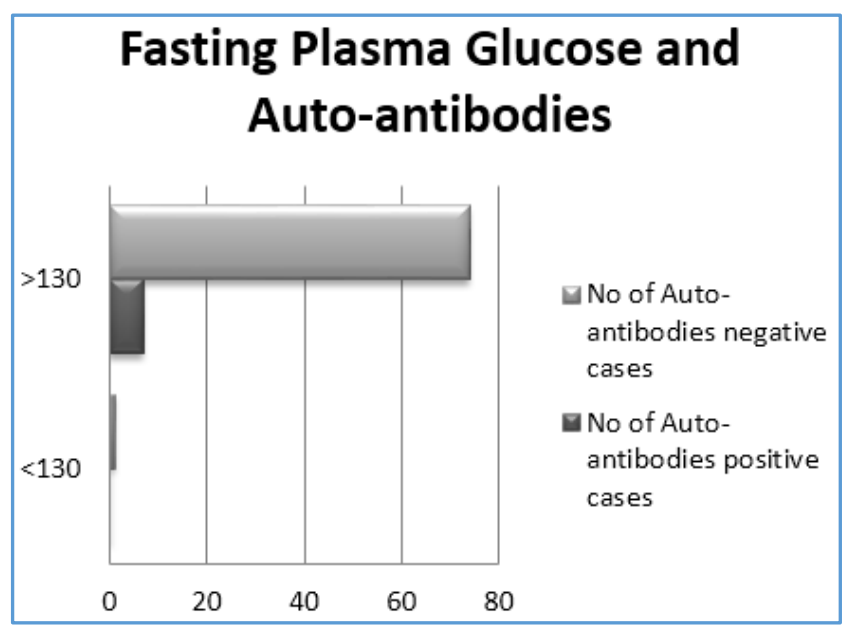

\section{RESULTS}

Total number of participants in this study was 82 in number. In this study group 43(52.44\%) were females and 39 $(47.56 \%)$ were males. On analysis of 82 people for the presence of autoantibodies to GAD-65 and IA-2, 7 were positive which represents $8.53 \%$ in percentage. Of the two autoantibodies, antibodies to GAD was prevalent in adults and was seen in 6 peoples whereas IA- 2 was seen in one patient and none of the patients in this study showed positivity for both autoantibodies. 


\section{Age and Autoantibodies Positivity}

Out of 7 positive for autoantibodies patients, 5 were in the age group between 21 to 30 years of age and 2 were in between the age group of 31-40 years of age. Although there was no statistical significance in the age distribution between autoantibodies positive group from the autoantibodies negative group, clustering of autoantibodies positive cases occurs earlier.

\section{Sex and Autoantibodies Positivity}

In sex ratio within the autoantibody positive group, out of 7 autoantibodies positive $5(71.4 \%)$ of them were male and $2(28.6 \%)$ of them were female.

On analysing the sex ratio between antibody positive group vs antibody negative group, out of 39 males participated 5(12.8\%) were positive for autoantibodies and in case of female out of 43 participants $2(4.7 \%)$ were positive for autoantibodies. There was no statistical significance between these two groups.

Family History of Diabetes and Autoantibodies Positivity Both the autoantibodies positive group and negative group did not show any variations regarding the prevalence of family history in their group. In positive group 2 patients had a positive family history of diabetes out of total 7 patients. In negative group 42 cases out of 75 cases showed positive family history.

\section{Duration of Diabetes}

Antibodies positive group did not vary from that of negative group in the aspect of duration of the study. Out of 7 autoantibodies positive patients, 6 patients presented with duration of diabetes less than 2 years whereas out of 75 autoantibodies negative group 51 cases presented with less than 2 years duration.

The demographic parameters such as age, sex, duration of diabetes and family history did not differ between the two groups. So, using the age or family history as cut off to diagnose type 1 or type 2 diabetes clinically becomes blurred. Clinical and Laboratory profile:

\section{Body Mass Index (BMI)}

Reference for body mass index in our study was adopted from the guidelines released by Health Ministry- Government of India, Indian Council of Medical Research (ICMR) and the National Institute of Nutrition (NIN).

Body mass index between these two groups showed no statistical variations which is also required as screening eligibility for the study. On comparing the median BMI between these two groups autoantibodies positive group median BMI $(22.47 \pm 2.03)$ was lower than that of antibodies negative group $(24.45 \pm 3.88)$.

\section{Waist Circumference and Autoantibodies Positivity}

As per the ICMR recommendation; cut off limit for waist circumference is below $90 \mathrm{cms}$ for Indian men and $80 \mathrm{cms}$ for Indian women.

In case of male population in our study, out of 5 autoantibodies positive patient one patient had central obesity whereas 27 patients of total 75 autoantibodies negative patients had central obesity of waist circumference more than $90 \mathrm{cms}$. On statistical analysis, these findings became not significant.
In case of female participants in our study none of the antibody positive patient had central obesity whereas 30 out of 43 female participants had waist circumference more than $80 \mathrm{cms}$ fitting in the criteria for central obesity. However, autoantibodies positive female number is less this cannot be extrapolated to a huge population. On statistical analysis of these parameters comparing both the groups, waist circumference was not varying between the two groups.

\section{Fasting C-peptide Concentration and Autoantibodies Positivity}

Estimation of fasting C-peptide which is surrogate marker of endogenous insulin secretion was done in all the 82 participants and compared with the two groups.

Comparison revealed statistical significance between the two groups. All the 7 autoantibodies patients showed marked reduction in the plasma fasting $\mathrm{C}$-peptide concentration. In the autoantibodies negative group out of 75 patients, only 5 patients showed significant low levels of plasma C-peptide concentration.

\section{Metabolic Syndrome and Autoantibodies Positivity}

Estimation of systolic and diastolic blood pressure between the two groups was done to analyse the prevalence of metabolic syndrome. Mean systolic BP in antibody positive group is $117.14 \pm 4.88$ whereas in the antibody negative group is $117 \pm 7.01$ which was statistically insignificant. Mean diastolic BP in the antibody positive group is $82.29 \pm 7.06$ where mean diastolic BP in the antibody negative group is $78.83 \pm 5.47$ which is also statistically insignificant.

\section{Triglycerides and Autoantibody Positivity}

Mean triglycerides level in autoantibody positive group is $186.86 \pm 34.84$ whereas mean triglycerides level in autoantibody negative group is $164.47 \pm 63.50$. Statistical analysis revealed there is no significant difference between these two groups.

\section{HDL and Autoantibody Positivity}

HDL analysis revealed statistical significance between the two groups. Mean HDL in autoantibody group is $41 \pm 1.41$ whereas in autoantibody negative group is $38.61 \pm 4.62$.

Insulin usage in the management of diabetes and autoantibodies positivity.

Out of 7 autoantibodies positive patients 2 patients were on insulin before the enrolment into study and 16 patients out of 75 patients in autoantibodies negative group were on insulin before the start of the study. Statistically insulin usage between the two groups was not significant.

\section{Fasting Plasma Glucose and Autoantibodies Positivity}

Fasting plasma glucose between the autoantibodies positive and autoantibodies negative group did not reveal any statistical significance. Mean fasting glucose in autoantibodies positive group is $179 \pm 14.99$ whereas in the autoantibodies negative group is $173.99 \pm 25.86$.

Thus, the BMI and Waist circumference which are the markers for assessing obesity is not fruitful to differentiate between autoimmune type 1 and type 2 diabetes mellitus. 


\section{CONCLUSION}

Diagnosing type 2 diabetes in young individuals by using the classical clinical criteria such as age and weight must be revised as these patients may have evidence for autoimmune destruction of islet of pancreas. These antibody positive individuals have similar demographic, clinical as well as biochemical profile as that of type 2 diabetes. Thus, screening autoantibodies is useful to distinguish between type 1 diabetes and type 2 diabetes in young.

\section{Acknowledgement}

Authors would like to thank all the participants of the study. Authors also acknowledge the immense help received from the faculty of department of Immunology, the Tamil Nadu Dr. M. G. R. Medical University, Chennai and scholars whose articles are cited and included in reference of this manuscript. The authors are also grateful to authors, editors and publishers of all those articles, journals and books from where the literature for this article has been reviewed and discussed.

\section{REFERENCES}

[1] Definition and diagnosis of diabetes mellitus and intermediate hyperglycemia: Report of a WHO/IDF consultation World Health Organization 2006.

[2] American Diabetes Association. Diagnosis and classification of diabetes mellitus. Diabetes Care 2010;33(Supplement 1):S62-9.

[3] Pinhas-Hamiel O, Dolan LM, Daniels SR, et al. Increased incidence of non insulin dependent diabetes mellitus among adolescents. Jour Pediatr 1996;128(5 Pt 1):60815.

[4] Dabelea D, Hanson RL, Bennett PH, et al. Increasing prevalence of type 2 diabetes mellitus in American Indian children. Diabetologia 1998;41(8):904-10.

[5] Klingensmith GJ, Pyle LMS, Arstanian S, et al. The presence of GAD and IA-2 antibodies in youth with a type 2 diabetes phenotype. Diabetes Care 2010;33(9):1970-5. 